\title{
Fibrinogen-independent Platelet Adhesion and Thrombus Formation on Subendothelium Mediated by Glycoprotein Ilb-Illa Complex at High Shear Rate
}

Harvey J. Weiss, Jacek Hawiger, Zaverio M. Ruggeri, Vincent T. Turitto, Perumal Thiagarajan, and Thomas Hoffmann The Department of Medicine, St. Luke's-Roosevelt Hospital Center and Columbia University College of Physicians and Surgeons, New York, New York 10032; The Department of Medicine, New England Deaconess Hospital and Harvard Medical School, Boston, Massachusetts 02215; the Department of Basic and Clinical Research, Division of Experimental Hemostasis, Scripps Clinic and Research Foundation, La Jolla, California 92037; the Department of Medicine, Mt. Sinai School of Medicine, New York, New York 10029; and the Department of Medicine, University of Washington, Seattle, Washington 98195

\begin{abstract}
Platelet adhesion and thrombus formation on subendothelium, studied at a shear rate of $2,600 \mathrm{~s}^{-1}$, were inhibited by two synthetic peptides known to interact with GPIIb-IIIa. One peptide (HHLGGAKQAGDV) corresponds to the carboxyl terminal segment of the fibrinogen $\gamma$-chain $(\gamma 400-411)$ and the other (RGDS) contains the amino acid sequence Arg-Gly-Asp (RGD) common to fibronectin, von Willebrand factor, vitronectin and the $\alpha$-chain of fibrinogen. Neither platelet adhesion nor thrombus formation were decreased in a patient with severe congenital fibrinogen deficiency and this was equally true when his blood was further depleted of the small amounts of fibrinogen present utilizing an anti-fibrinogen antibody. In normal subjects, adhesion and thrombus formation were inhibited by the Fab' fragments of a monoclonal anti-GPIIb-IIIa antibody ( $\mathrm{LJ}-\mathrm{CP8}$ ), which interferes with the interaction of platelets with all four adhesive proteins in both the fluid and solid phase. However, another anti-GPIIb-IIIa antibody (LJ-P5) that had minimal effects on the interaction of platelets with fibrinogen, but inhibited to varying degrees platelet interaction with other adhesive proteins, was equally effective. The findings demonstrate that, at a shear rate of $2,600 \mathrm{~s}^{-1}$, adhesive proteins other than fibrinogen are involved in GPIIb-IIIa-mediated platelet adhesion and thrombus formation on subendothelium. In addition, since LJ-P5 inhibited the binding of soluble von Willebrand factor and vitronectin, these adhesive proteins may be involved in platelet thrombus formation. In contrast to the results obtained at a shear rate of $2,600 \mathrm{~s}^{-1}$, fibrinogen could play a role in mediating platelet-platelet interactions with weak agonists or lower shear rates.
\end{abstract}

\section{Introduction}

Considerable clinical and experimental evidence (1-3) indicates that von Willebrand factor ( $v W f$ ), through binding to platelet glycoprotein Ib (GPIb) ${ }^{1}$ (4-8), mediates the initial at-

Address reprint requests to Dr. Weiss, St. Luke's-Roosevelt Hospital Center, 428 West 59th Street, New York, NY 10019.

Received for publication 31 August 1987 and in revised form 24 July 1988.

1. Abbreviations used in this paper: GP, glycoprotein.

J. Clin. Invest.

(c) The American Society for Clinical Investigation, Inc. $0021-9738 / 89 / 01 / 0288 / 10 \quad \$ 2.00$

Volume 83, January 1989, 288-297 tachment of platelets to subendothelium $(9,10)$ and hence promotes their adhesion to this surface when studied in ex vivo flow chambers under conditions of high shear rate (11-17). Recent studies suggest that the subsequent spreading of platelets on the surface (which promotes irreversible adhesion), as well as platelet aggregate formation (thrombi), are mediated by the platelet membrane receptor GPIIb-IIIa (18-20). Since GPIIb-IIIa is the platelet fibrinogen receptor $(21,22)$, it seemed reasonable to assume that fibrinogen is the adhesive protein involved in GPIIb-IIIa-mediated platelet interaction with the vessel wall. This concept could also account for the observation that thrombasthenic platelets (which lack GPIIbIIIa) do not form thrombi when subendothelium is exposed to blood at physiologic shear rates $(18,19)$, or aggregate in response to physiologic agonists $(1,2)$. This left unexplained, however, the observations that platelets of patients with severe deficiencies of fibrinogen aggregate normally with collagen and thrombin (23-25) [but abnormally with ADP (23-26)], and form thrombi when exposed to subendothelium at physiologic shear rates $(27,28)$. Subsequently, it was shown that vWf can also bind to ADP or thrombin-stimulated platelets $(29,30)$ through GPIIb-IIIa $(7,8,31,32)$, and can substitute for fibrinogen in platelet aggregation tests performed either in patients with afibrinogenemia (24) or with washed normal platelets (33). In addition, fibronectin (34) and vitronectin (35) also bind to GPIIb-IIIa in thrombin-stimulated platelets. The concept that these adhesive proteins share a common receptor mechanism (GPIIb-IIIa) on platelets is supported by the observations that their binding to GPIIb-IIIa can be blocked by synthetic peptides, either corresponding to the carboxyl terminus of the fibrinogen $\gamma$-chain $(36,37,38)(\gamma 400-411)$ or containing the sequence Arg-Gly-Asp (RGD) common to fibronectin, vWf, the $\alpha$-chain of fibrinogen, and vitronectin (39-45). The above studies suggest that adhesive proteins other than fibrinogen could be physiologic ligands mediating platelet adhesion and thrombus formation on subendothelium.

The present series of experiments were undertaken to explore further the role of GPIIb-IIIa, and its adhesive protein ligands, in mediating platelet adhesion and thrombus formation on subendothelium under conditions of high shear stress. To do this, we studied the effects on normal human platelets of both the $\gamma 400-411$ peptide and a peptide (RGDS) containing the RGD sequence, as well as two monoclonal antibodies against GPIIb-IIIa, one of which has a minimal effect of fibrinogen binding to stimulated platelets $(46,47)$. Additional experiments were performed to assess the effect of these antibodies on the adhesion of activated platelets to surface-bound adhesive proteins, as well as their effects on the binding of 
soluble vitronectin. Experiments were also performed using blood from a patient with a severe congenital deficiency of fibrinogen, including studies in which his blood was preincubated with an antibody to human fibrinogen in order to reduce further, or eliminate, any effects of the trace amounts of fibrinogen that are present in his blood. We present evidence that fibrinogen is not the adhesive ligand involved in GPIIbIIIa mediated platelet adhesion or thrombus formation on subendothelium at a high shear rate $\left(2,600 \mathrm{~s}^{-1}\right)$, although it could be involved in platelet-platelet interaction at lower shear rates or with weak platelet agonists. Our findings also support the concept that vWf, and possibly vitronectin, may be essential for thrombus formation under conditions of high shear stress.

\section{Methods}

Blood. Blood was obtained by venipuncture and mixed with $1 / 10 \mathrm{vol}$ of $3.2 \%$ sodium citrate dihydrate. This citrated blood was used for perfusion experiments, and for preparation of both platelet-rich plasma (PRP) and washed platelets, as described below. All studies were performed under a protocol approved by the Institutional Review Board of the St. Luke's-Roosevelt Institute for the Health Sciences.

Perfusion experiments. Everted segments of deendothelialized rabbit aorta, previously denuded of endothelium by means of a balloon catheter, were exposed, in an annular perfusion chamber, to recirculated citrated blood, adjusted for the hematocrit value to a final plasma concentration of $19.7 \mathrm{mM}$ citrate $(11,13,14,48,49)$. In this system, blood entering the chamber passes through the annular space formed by the subendothelial surface and the outer cylinder wall, thereby permitting platelets to interact with the exposed subendothelial surface. The flow parameters, dimensions, and temperature $\left(37^{\circ} \mathrm{C}\right)$ control for the chamber have been previously described $(13,48)$. Blood was circulated through the chamber in a closed system using a peristaltic pump to maintain a blood flow of $40 \mathrm{ml} / \mathrm{min}$ and a calculated wall shear rate of $2,600 \mathrm{~s}^{-1}$. In selected studies, a shear rate of $800 \mathrm{~s}^{-1}$ (18) was also used.

After perfusion, vessel segments were embedded in an oriented manner and cross sections, $0.8 \mu \mathrm{m}$ in thickness, were stained and evaluated morphometrically by light microscopy $(9,11,13,14)$. Platelet interaction with subendothelium was calculated systematically at $10-\mu \mathrm{m}$ intervals at two axial positions located $\sim 5$ and $8 \mathrm{~mm}$ from the proximal end of the segment, and the results of the two determinations for each segment were averaged. Contact platelets $(C)$ are platelets that are attached to, but not spread on the subendothelium. Spread platelets (S) are platelets that have spread on the subendothelial surface. Thrombi $(\mathrm{T})$ are defined as a platelet thrombus $5 \mu \mathrm{m}$ or more in height which is superimposed on spread platelets. Platelet adhesion, defined as $\mathrm{C}+\mathrm{S}$, and thrombus formation, defined as $\mathrm{T}$, are expressed as percentage of the total number of evaluations $(\sim 1,000)$ per vessel segment.

Platelet aggregation. Platelet aggregation studies on citrated PRP or washed platelets were performed in a dual channel aggregation module (Payton Associates, Buffalo, NY), and results were expressed as the maximal percent change in light transmission relative to platelet-poor plasma (50). Citrated PRP was prepared from citrated blood by centrifugation at $1,500 \mathrm{~g}$ for $3 \mathrm{~min}$ at $22^{\circ} \mathrm{C}$. For some studies (collagen and ADP dose-response curves), the platelet count was adjusted to $200,000 / \mu 1$ with autologous platelet-poor plasma and the adjusted PRP distributed in 1-ml aliquots into aggregometer cuvettes and sealed with parafilm under $\mathrm{CO}_{2}$ until utilized for aggregation studies. The $\mathrm{pH}$ of the adjusted PRP was measured before and after aggregation studies and varied from values of 7.67 to 7.70 . To prepare washed platelets (for thrombin dose-response studies), citrated PRP was first layered onto albumin density gradients and platelets were isolated and concentrated by albumin density gradient centrifugation (51). The concentrated platelets were then gel-filtered into calcium-free
Tyrode's buffer, $\mathrm{pH}=7.4$ containing $0.2 \%$ bovine albumin (52) and the platelet count adjusted to $200,000 / \mu$ l. Agonists utilized during various parts of the study included ADP (Sigma Chemical Co, St. Louis, MO), equine tendon acid insoluble type I collagen (Hormon Chemie, Munich, FRG) or purified human $\alpha$-thrombin (a generous gift of Dr. John Fenton obtained through the Office of Biologic Research and Review, Bethesda, MD).

Binding assays-soluble proteins. The binding of soluble vWF, fibrinogen, and fibronectin to thrombin and ADP-stimulated platelets, and of monoclonal antibodies to platelets in PRP, has been described previously $(46,47)$. For studies on the binding of vitronectin, the latter was isolated from normal plasma as described by Dahlback (53), with some modification (35), and radiolabeled with ${ }^{125} \mathrm{I}$ by the BoltonHunter reagent (54), as previously described (35). The labeled vitronectin (sp act $397 \mathrm{cpm} / \mathrm{ng}$ ) was stored in a buffer of $\mathrm{pH} 7.5$ containing $0.15 \mathrm{M} \mathrm{NaCl}$ and $0.02 \mathrm{M}$ Tris (Tris-buffered saline, TBS), $1 \mathrm{mM}$ reduced glutathione, and 5\% BSA. Studies on the binding of ${ }^{125} \mathrm{I}-\mathrm{la}-$ beled vitronectin to suspensions of thrombin-treated washed platelets were performed as recently described (35). To study the effects of antibodies on vitronectin binding, a suspension of $200 \mu \mathrm{l}$ of platelets $\left(3.5 \times 10^{8} / \mathrm{ml}\right)$ was incubated with the monoclonal antibodies (see below) for 10 minutes at room temperature. Various concentrations of ${ }^{125}$ I-labeled vitronectin were added, followed by thrombin to a final concentration of $0.5 \mathrm{U} / \mathrm{ml}$. Final volume of the incubation mixture was kept constant at $330 \mu \mathrm{l}$. At the end of $30 \mathrm{~min}$, the entire contents of the incubation mixture was layered onto silicone oil in a micro-sedimentation tube and centrifuged at $10,000 \mathrm{~g}$ for $2 \mathrm{~min}$ at room temperature in an Eppendorf centrifuge. After sedimentation, the tips of the centrifuge tubes containing the platelet pellet were sliced with a dog nail clipper, and the pellet and the supernatant were counted separately in a gamma counter (Searle Analytic Inc., Chicago, IL). Since $10 \mathrm{mM}$ EDTA completely inhibited specific binding in dose-response isotherms, nonspecific binding was determined as residual binding in the presence of $10 \mathrm{mM}$ EDTA.

Adhesion studies-surface bound proteins. The adhesion of thrombin-activated platelets to immobilized (surface bound) adhesive proteins, and the effect of antibodies, were studied utilizing the ELISA plate assay described by Haverstick et al. (55). Vitronectin was prepared and radiolabeled as described above. vWf, fibrinogen, and fibronectin were isolated as described previously $(7,56,57)$. Fibrinogen was further purified by passing through a column of gelatin agarose. The final preparations were not contaminated with other proteins when tested by Ouchterlony double immunodiffusion and, in the case of vWf, by immunoblotting with monospecific antibodies following SDS PAGE (7). Substrates for platelet adhesion were prepared in 96 well ELISA plates (Falcon 3915; Becton Dickinson and Co., Lincoln Park, NJ). A 200- $\mu$ l solution containing various amounts of vitronectin $(1 \mu \mathrm{g})$, fibronectin $(0.5 \mu \mathrm{g})$, fibrinogen $(10 \mu \mathrm{g})$, and $\mathrm{vWf}(5 \mu \mathrm{g})$ in TBS was added to the wells, and the plates were incubated at room temperature for $2 \mathrm{~h}$. These concentrations of adhesive proteins gave the maximal binding of platelets in dose-response isotherms. After incubation, the solutions were aspirated, and the wells were filled with TBS containing $1 \%(\mathrm{wt} / \mathrm{vol})$ bovine serum albumin. Control wells were filled with albumin only.

Adhesion assays were performed as described by Haverstick et al. (55). Blood was mixed (9:1) with 3.8\% trisodium citrate, $\mathrm{pH} 6.5$, and PRP obtained by centrifugation at $1,000 \mathrm{~g}$ for $3 \mathrm{~min}$ at room temperature. Following addition of prostaglandin $\mathrm{E}_{1}$ (Sigma Chemical Co.) in a final concentration of $1 \mu \mathrm{M}$, platelets were sedimented by centrifugation at $1,000 \mathrm{~g}$ for $12 \mathrm{~min}$ at room temperature. After the initial centrifugation, the platelets were suspended in $1 \mathrm{ml}$ of platelet washing buffer and incubated for 30 min with $100 \mu \mathrm{Ci} \mathrm{Na}{ }^{51} \mathrm{CrO}_{4}$. The platelet suspension was then washed thrice as described by Baenziger and Majerus (58). The platelets were suspended for adhesion assays in a pH 7.5 buffer containing $0.14 \mathrm{M} \mathrm{NaCl}, 0.012 \mathrm{M} \mathrm{NaHCO}{ }_{3}, 5 \mathrm{mM}$ Hepes, 5 $\mathrm{mM}$ dextrose and $10 \mathrm{mg} / \mathrm{ml} \mathrm{BSA}$. Equal volumes of platelet suspension and various concentrations of antibodies (see below) were incubated for $10 \mathrm{~min}$ at room temperature, and thrombin was added to a 
final concentration of $0.5 \mathrm{U} / \mathrm{ml}$. The thrombin was neutralized with 2 $\mathrm{U} / \mathrm{ml}$ of hirudin (Sigma Chemical Co.). The mixture was incubated for $20 \mathrm{~min}$ at room temperature without shaking. $100-\mu \mathrm{l}$ aliquots of the platelet suspension were then transferred to the plates coated with the protein and incubated at room temperature for $60 \mathrm{~min}$ without shaking. At the end of the incubation period, nonadherent platelets were removed by rinsing and aspiration in the binding buffer. The extent of binding was determined by incubating the wells sequentially with two $300-\mu l$ portions of $2 \%(\mathrm{wt} / \mathrm{vol})$ of SDS for $20 \mathrm{~min}$ each. The extracts were pooled and the ${ }^{51} \mathrm{Cr}$ content was determined. In all experiments, adhesion to albumin was performed as negative control. As described by Haverstick et al. (55), precautions were taken to avoid platelet aggregation during the incubation procedure, including avoidance of shaking, and incubation at room temperature, rather than at $37^{\circ} \mathrm{C}$ (56). No aggregates were detected by phase microscopic examination.

Synthetic peptides. A dodecapeptide (HHLGGAKQAGDV) analogous to the carboxy-terminal segment of human fibrinogen $\gamma$-chain $(\gamma 400-411)(59)$ was synthesized by the solid-phase method $(60)$ as previously described (59). This method was also used to synthesize the tetrapeptide RGDS containing the RGD sequence common, among other proteins, to fibronectin, vWf, vitronectin, and the $\alpha$-chain of fibrinogen (39-45). The amino acid composition of the peptides was determined and the purity was checked on analytical high-performance liquid chromatography according to established methods (59). In one study, an RGDS peptide kindly donated by Dr. Kenneth Yamada (National Institutes of Health, Bethesda MD) was utilized, and analysis demonstrated identical composition to RGDS peptides utilized in other parts of the study. In some studies, the effects of a control peptide IPVAIKEL, prepared as above, was also tested.

Anti-human fibrinogen Fab fragments. Serum from rabbits immunized with human fibrinogen (Kabi Vitrum, Stockholm, Sweden) was passed through a fibrinogen-sepharose affinity column and the monospecific immunoglobulin fraction was eluted with $0.1 \mathrm{M}$ glycine- $\mathrm{HCl}$, pH 2.4 (61). After dialysis, Fab fragments were prepared according to the procedure of Porter (62) and purified by chromatography on $\mathrm{CM}$ Sepharose 4BCL using a $0-0.4 \mathrm{M} \mathrm{NaCl}$ gradient in $0.05 \mathrm{M} \mathrm{Na}$ acetate, pH 5.0 (63). The Fab anti-fibrinogen antibody inhibited the binding of soluble fibrinogen to ADP-treated platelets, and aggregation by ADP of a suspension of washed platelets containing fibrinogen, but not vWf (33).

$M A b$ to glycoprotein IIb-IIIa. The preparation and characterization of two of the monoclonal anti-GPIIb-IIIa antibodies used in these studies, LJ-CP8 and LJ-P5, have been described previously $(46,47)$. The third antibody used, LJ-P10, was obtained from the same fusion from which LJ-P5 was obtained. All three antibodies were of the "complex specific" type, i.e., they bound to GPIIb and/or GPIIIa when the two glycoproteins were complexed, but not after they had been dissociated. This was shown by failure of the antibodies to bind to platelets in PRP that had been incubated for $20 \mathrm{~min}$ at $37^{\circ} \mathrm{C}$ in the presence of $5 \mathrm{mM}$ EDTA and at $\mathrm{pH} 8$. In contrast, when the antibodies were added to citrated PRP at pH 7.6-7.8 and before the addition of EDTA, they bound to $\sim 50,000$ molecules/platelet.

In previous studies $(46,47), \mathrm{LJ}-\mathrm{CP} 8$ inhibited the binding of soluble fibrinogen, vWF, and fibronectin to thrombin-stimulated washed platelets in a dose-dependent manner. The concentration of antibody (monovalent $\mathrm{Fab}^{\prime}$ fragment) required to inhibit binding completely was between 20 and $40 \mu \mathrm{g} / \mathrm{ml}$. In the present study, LJ-CP8 was also found to inhibit by $75 \%$ the binding of soluble vitronectin (under saturating conditions) to thrombin-stimulated platelets. As previously reported (46), LJ-P5 inhibits the binding of soluble vWF to thrombinstimulated platelets, but does not inhibit the binding of fibrinogen or fibronectin. The concentration of LJ-P5 (monovalent Fab' fragments) that completely inhibits the binding of VWF to thrombin-stimulated platelets is $40 \mu \mathrm{g} / \mathrm{ml}$. In the present study, LJ-P5 also inhibited by $50 \%$ the binding of soluble vitronectin to thrombin-stimulated platelets, studied as above. Unlike the other two antibodies, LJ-P10 (intact IgG or monovalent $\mathrm{Fab}^{\prime}$ ) did not inhibit the binding of any of the ligands tested even when used at concentrations as high as $200 \mu \mathrm{g} / \mathrm{ml}$.
Because of the fact that the perfusion studies were performed with whole blood, we conducted experiments to determine the concentration of antibody that was necessary to add to whole blood in order to have saturation of the corresponding epitopes. In these experiments, citrated blood was mixed with increasing concentrations of ${ }^{125}$ I-labeled LJ-P5 or LJ-CP8 $\mathrm{Fab}^{\prime}$ and incubated for $30 \mathrm{~min}$ at $22-25^{\circ} \mathrm{C}$. At the end of the incubation period, PRP was prepared by centrifugation of the whole blood, the platelets were counted and then separated from free antibody by centrifugation through $20 \%$ sucrose. The amount of radioactivity associated with the platelet pellet was measured in a scintillation spectrometer and the amount of antibody bound per platelet was estimated from the known specific activity. Saturation of binding was found to occur with $7 \mu \mathrm{g} / \mathrm{ml}$ of LJ-P5 and $12 \mu \mathrm{g} / \mathrm{ml}$ of LJ-CP8 added to whole blood.

Experimental system for studies of the effect of synthetic peptides and antibodies on platelet-subendothelial interaction. All studies were performed by incubating $30 \mathrm{ml}$ of citrated blood with a total volume of $0.5 \mathrm{ml}$ containing various proportions of test substance and Tris- $-(0.02$ M)-saline $(0.15 \mathrm{M})$ buffer, $\mathrm{pH}=7.4$ for $1 \mathrm{~min}$ at $37^{\circ} \mathrm{C}$ before the 5 -min perfusion of the everted vessel segments. In most experiments, postperfusion blood was centrifuged to obtain PRP for platelet aggregation studies. For each set of experiments, the results obtained for test substances were expressed as the percentage of the value (100\%) obtained on the concurrent control (Tris-saline) samples obtained on the same day. Values that differed from the control with a $P$ value of 0.05 or less (Student's $t$ test) were considered significant.

Subjects. Control subjects for the perfusion experiments in this study were seven normal hospital employees who had not ingested aspirin or other drugs known to affect platelet function for at least 1 wk. The average blood values in these subjects were: plasma vWf:antigen, $93 \mathrm{U} / \mathrm{dl}$ (range 73-125), plasma fibrinogen $276 \mathrm{mg} / \mathrm{dl}$ (range 200-320), platelet count 247,000/ $\mu$ l (range 190,000-310,000).

Patient C.M., afibrinogenemia. Patient C.M. is a 37 -yr-old man with a severe deficiency of fibrinogen who has been the subject of previous studies (26-28). For the present set of experiments, he was studied on five different occasions. A previously reported value for his plasma fibrinogen was $3 \mu \mathrm{g} / \mathrm{ml}$ (i.e., $\sim 1 / 1,000$ normal) obtained by RIA of fibrinopeptide A after $30 \mathrm{~min}$ incubation of his plasma with 1 $\mathrm{U} / \mathrm{ml}$ thrombin (28). In the present study, a value of $5 \mu \mathrm{g} / \mathrm{ml}$ was obtained by the double antibody method of Kaplan and Owen (63) utilizing a rabbit anti-fibrinogen (Cappel Laboratories, Inc., Cochranville, PA) and goat anti-rabbit immunoglobulin (Miles Laboratories, Inc., Naperville, IL). Purified human fibrinogen was used as standard (assay kindly performed by Dr. John Owen, Columbia University). This anti-fibrinogen antibody recognizes an epitope in the D-domain of the fibrinogen molecule (64). Using the latter antibody, the platelet fibrinogen value in C.M. (obtained by RIA of a lysate of washed, sonicated platelets [50]) was $\sim 1 / 50$ normal $\left(1.9 \mu \mathrm{g} / 10^{9}\right.$ platelet compared with values in eight normal subjects of $\left.60-114 \mu \mathrm{g} / 10^{9}\right)$. The average value for his platelet count was $270,000 / \mu$ l (range 251,000 310,000 ). Thus, the fibrinogen content in his blood was $\sim 0.5 \mu \mathrm{g} / \mathrm{ml}$ from platelets and 3-5 $\mu \mathrm{g} / \mathrm{ml}$ from plasma. The plasma vWf:antigen in patient C.M. was $130 \mathrm{U} / \mathrm{dl}$ (range 95 to $170 \mathrm{U} / \mathrm{dl}$ ).

von Willebrand's disease. Subjects studied were three previously reported patients with severe (type III) von Willebrand's disease whose plasma vWf:antigen levels were $<6 \mathrm{U} / \mathrm{dl}$ by Laurell electroimmunoassay (normal values 55-161) and $<0.004 \mathrm{U} / \mathrm{dl}$ by immunoradiometric assay (65).

\section{Results}

\section{Platelet-subendothelial interactions: baseline values}

Values (mean \pm SEM) for platelet adhesion $(C+S)$ and thrombi $(\mathrm{T})$ obtained in the present study were comparable to those obtained previously (18) in normal subjects $(C+S$ $=47.7 \pm 4.1$ vs $47.7 \pm 4.4 \%$ previously and $T=12.6 \pm 3.1$ vs. $8.5 \pm 1.6 \%$ previously). The average baseline value (five sepa- 

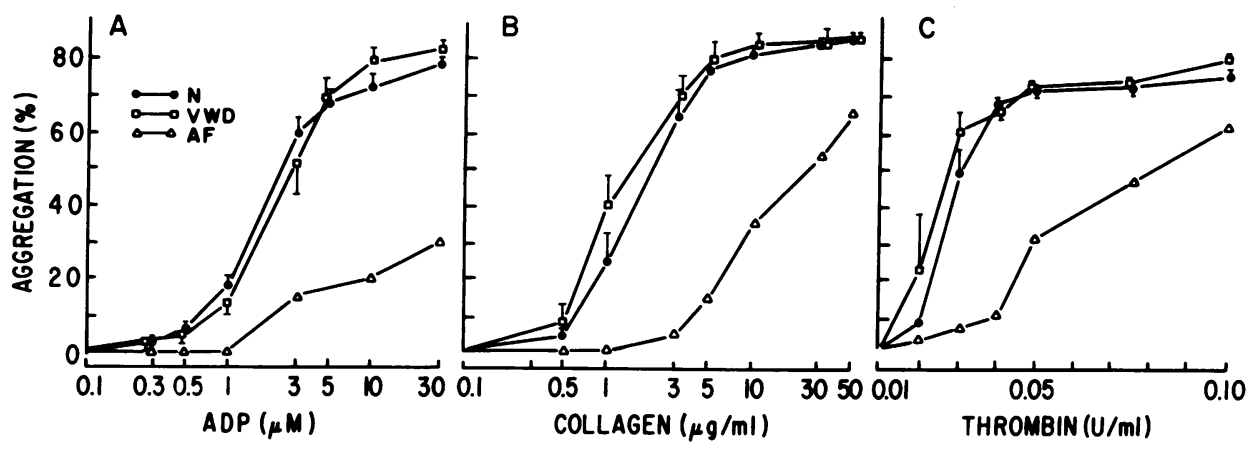

Figure 1. Platelet aggregation. Left and middle $(A$ and $B$ ) Aggregation of platelets in PRP by $(A)$ collagen $(B)$ ADP. (C) Aggregation by thrombin of platelets washed by albumin-density centrifugation and gel filtration. Results shown $( \pm \mathrm{SE})$ for normal subjects $(\bullet)$, three patients with severe von Willebrand's disease ( $\square$ ), and patient C.M. with afibrinogenemia $(\Delta)$. rate occasions) for platelet adhesion $(C+S)$ in patient C.M. with afibrinogenemia was $79.7 \pm 4.6 \%$; , for platelet thrombi $(\mathrm{T})$ it was $9.6 \pm 1.5 \%$.

\section{Platelet aggregation-dose response studies}

Dose-response curves for collagen and ADP (utilizing citrated PRP, adjusted to constant $\mathrm{pH}$ and platelet count) and thrombin (utilizing gel-filtered platelets, GFP) are shown in Fig. 1. In patient C.M. with afibrinogenemia, aggregation was decreased (compared with normal subjects) at all concentrations of ADP, and at the lower concentrations of both collagen and thrombin. In contrast, aggregation with collagen and thrombin became normal with increasing concentrations of these agonists. Aggregation responses with all agonists were consistently normal in patients with severe von Willebrand disease.

\section{Effect of adding synthetic peptides to blood}

Addition of synthetic peptides RGDS and $\gamma 400-411$ to blood before perfusion inhibited platelet adhesion $(C+S)$ in a dosedependent manner in both normal subjects and patient C.M. with afibrinogenemia (Table I). However, even with the highest concentration used ( $500 \mu \mathrm{M})$, neither peptide completely inhibited adhesion. In all cases, adhesion values were $20-50 \%$ of the control values (addition of buffer alone) (Table I). Thrombus formation was also inhibited by both peptides, and to a greater extent than adhesion (Table I). Thus, with a $500-\mu \mathrm{M}$ concentration of both peptides, virtually no thrombi (> $5 \mu \mathrm{m}$ in height) were observed in either normal subjects or patient C.M. A control peptide (IPVAIKEL) studied in four normal subjects at a concentration of $500 \mu \mathrm{M}$ had no effect on

Table I. Effect of Synthetic Peptides on Platelet-Subendothelial Interaction

\begin{tabular}{|c|c|c|c|c|c|c|}
\hline \multirow[b]{2}{*}{ Peptide } & \multirow[b]{2}{*}{$\begin{array}{c}\text { Blood } \\
\text { concentration }\end{array}$} & \multirow[b]{2}{*}{$n$} & \multicolumn{2}{|c|}{ Normal Subjects } & \multicolumn{2}{|c|}{ Afibrinogenemia } \\
\hline & & & $\begin{array}{c}\text { Adhesion } \\
(C+S)\end{array}$ & $\begin{array}{l}\text { Thrombi } \\
\text { (T) }\end{array}$ & $\begin{array}{l}\text { Adhesion } \\
(C+S)\end{array}$ & $\begin{array}{l}\text { Thrombi } \\
\text { (T) }\end{array}$ \\
\hline & $\mu M$ & & \multicolumn{4}{|c|}{ \% control (buffer) value } \\
\hline \multirow[t]{3}{*}{ RGDS } & 78 & 2 & $96 \pm 12$ & $45 \pm 23$ & $97 \pm 2$ & $158 \pm 14$ \\
\hline & 300 & 2 & $64 \pm 14$ & $0^{*}$ & $79 \pm 34$ & $50 \pm 35$ \\
\hline & 500 & 3 & $42 \pm 9 *$ & $0^{*}$ & $20 \pm 2^{*}$ & $0^{*}$ \\
\hline \multirow[t]{2}{*}{$\gamma 400-411$} & 25 & 2 & $89 \pm 26$ & $35 \pm 1 *$ & $67 \pm 13$ & $16 \pm 14$ \\
\hline & 500 & 3 & $46 \pm 6^{*}$ & $3 \pm 2 *$ & $50 \pm 11^{*}$ & $0^{*}$ \\
\hline
\end{tabular}

* Values (mean $\pm \mathrm{SEM})$ significantly less than controls $(P=0.05$ or less). platelet adhesion (106 $\pm 10 \%$ of control values) or thrombus formation ( $83 \pm 15 \%$ of control values).

To monitor our perfusion studies with a more commonly used procedure for studying platelet function, we also measured platelet aggregation on PRP prepared from postperfusion blood utilizing ADP (6 and $20 \mu \mathrm{M})$ and collagen ( 3 and 5 $\mu \mathrm{g} / \mathrm{ml})$. As seen in Table II, when compared with normal values, aggregation values at these concentrations of agonists were somewhat reduced in patient C.M. with afibrinogenemia. Studies on the postperfusion blood showed that addition of both peptides to normal blood resulted in incomplete inhibition of platelet aggregation in PRP by ADP $(6-20 \mu \mathrm{M})$ and collagen (3-5 $\mu \mathrm{g} / \mathrm{ml})$ and a greater degree of inhibition in afibrinogenemic PRP (Table II). A control peptide (IPVAIKEL) had no effect on platelet aggregation by ADP or collagen (data not shown).

\section{Effect of antibodies on the binding of activated platelets to immobilized proteins}

In addition to assessing the effects of the antibodies used in the study on the binding of soluble proteins to platelets $(46,47$ and Methods), their effects on the binding of activated platelets to immobilized proteins were also studied, as described in Methods.

The Fab anti-fibrinogen antibody inhibited the binding of activated platelets to immobilized fibrinogen by $97 \%$ at a concentration of $50 \mu \mathrm{g} / \mathrm{ml}$.

The effects of LJ-CP8 and LJ-P5 were studied in four normal subjects. Maximum inhibition by $\mathrm{LJ}-\mathrm{CP} 8$ occurred at an antibody concentration of $20-25 \mu \mathrm{g} / \mathrm{ml}$ and by LJ-P5 at a concentration of $5-10 \mu \mathrm{g} / \mathrm{ml}$. The inhibitory effects of LJ-CP8 were similar for the four protein substrates, as follows (percent inhibition of binding): vWf $86 \pm 2$ :, fibrinogen $85 \pm 2$ :, fibronectin $72 \pm 3$ :, and vitronectin $73 \pm 4$. In contrast, the percent inhibition of platelet adhesion to immobilized adhesive proteins by LJ-P5 was: vWf $68 \pm 3 \%$ :, fibrinogen $15 \pm 2 \%$ :, fibronectin $41 \pm 2 \%$; , and vitronectin $55 \pm 3 \%$.

\section{Effect of adding antibodies to blood}

ADDITION OF ANTIFIBRINOGEN Fab TO BLOOD OF PATIENT C.M. WITH SEVERE FIBRINOGEN DEFICIENCY

Since neither platelet adhesion nor thrombus formation in patient C.M. with afibrinogenemia appeared to be decreased compared to normal subjects (above), we performed studies on this subject's blood after addition of a monovalent Fab antibody fragment to fibrinogen (in a concentration of $114 \mu \mathrm{g} / \mathrm{ml}$ whole blood and $192 \mu \mathrm{g} / \mathrm{ml}$ plasma). The rationale for this experiment was that any functional capacity of the trace 


\begin{tabular}{|c|c|c|c|c|c|c|c|c|c|}
\hline \multirow[b]{3}{*}{ Addition } & \multirow{3}{*}{$\begin{array}{c}\text { Blood } \\
\text { concentration }\end{array}$} & \multicolumn{4}{|c|}{ Normal } & \multicolumn{4}{|c|}{ Afibrinogenemia } \\
\hline & & \multicolumn{2}{|c|}{ ADP } & \multicolumn{2}{|c|}{ Collagen } & \multicolumn{2}{|c|}{ ADP } & \multicolumn{2}{|c|}{ Collagen } \\
\hline & & 6 & 20 & 3 & 5 & 6 & 20 & 3 & 5 \\
\hline & & \multicolumn{8}{|c|}{$\%$ platelet aggregation* } \\
\hline \multirow[t]{2}{*}{ Control values (buffer) } & & $40 \pm 9$ & $66 \pm 7$ & $68 \pm 10$ & $86 \pm 8$ & $9 \pm 1$ & $33 \pm 3$ & $17 \pm 3$ & $36 \pm 7$ \\
\hline & & \multicolumn{8}{|c|}{ \% control value ${ }^{\ddagger}$} \\
\hline Control (buffer) & - & 100 & 100 & 100 & 100 & 100 & 100 & 100 & 100 \\
\hline RGDS & $500 \mu \mathrm{M}$ & $30 \pm 1$ & $35 \pm 1$ & $70 \pm 8$ & $73 \pm 2$ & 0 & 0 & $22 \pm 11$ & $14 \pm 8$ \\
\hline$\gamma 400-411$ & $500 \mu \mathrm{M}$ & $60 \pm 8$ & $60 \pm 10$ & $92 \pm 2$ & $106 \pm 5$ & 0 & 0 & $35 \pm 19$ & $46 \pm 20$ \\
\hline anti-Fib & $114 \mu \mathrm{g} / \mathrm{ml}$ & $109 \pm 18$ & $90 \pm 26$ & $97 \pm 4$ & $100 \pm 18$ & 0 & $35 \pm 3$ & $118^{\S}$ & $96^{\S}$ \\
\hline$\gamma 400-411+$ anti-Fib & above & - & $66 \pm 5$ & - & - & - & 0 & - & - \\
\hline LJ-P10 & $40 \mu \mathrm{g} / \mathrm{ml}$ & $80 \pm 16$ & $93 \pm 4$ & $75 \pm 1$ & $106 \pm 14$ & - & - & - & - \\
\hline LJ-CP8 & $40 \mu \mathrm{g} / \mathrm{ml}$ & 0 & 0 & 0 & 0 & 0 & 0 & 0 & 0 \\
\hline LJ-P5 & $40 \mu \mathrm{g} / \mathrm{ml}$ & $83 \pm 10$ & $86 \pm 11$ & $83 \pm 9$ & $88 \pm 10$ & $35 \pm 15$ & $42 \pm 3$ & $52 \pm 17$ & $71 \pm 22$ \\
\hline LJ-P5 + anti-Fib & above & - & - & - & - & 0 & 0 & 0 & 0 \\
\hline
\end{tabular}

* Average post perfusion values [all studies for platelet aggregation by ADP $(\mu \mathrm{M})$ and collagen $(\mu \mathrm{g} / \mathrm{ml})$ in control (buffer) blood.] Aggregation was measured as maximal increase in light transmission. ${ }^{\ddagger}$ Aggregation measured as above and the values expressed as a $\%$ of the value obtained for the control (buffer) for each agonist. ${ }^{\S}$ Performed in only 1 experiment.

amounts of fibrinogen present in his blood or absorbed onto the vessel segments would be blocked and, thus, the requirement of fibrinogen for platelet-subendothelial interactions would be more accurately assessed.

As seen in Table III, addition of the anti-fibrinogen (antiFib) antibody to the blood of patient C.M. did not reduce either platelet adhesion $(C+S)$ or thrombus formation (T) from their baseline values. Studies on the postperfusion blood showed that the antibody produced additional reduction in platelet aggregation by ADP (6 and $20 \mu \mathrm{M})$ whereas aggregation with collagen ( 3 and $5 \mu \mathrm{g} / \mathrm{ml}$ ) was unaffected (Table II).

EFFECT OF MAb TO GLYCOPROTEIN IIb-IIIa

$M A b$ LJ CP8: normal subjects and patient C.M. This monoclonal antibody, which blocks the binding of soluble and surface-bound adhesive proteins to GPIIb-IIIa [(47) and Methods], reduced the adhesion of platelets to subendothelium in normal and afibrinogenemic blood to $61 \pm 5$ and $48 \pm 7 \%$ of their control values respectively, and completely abolished thrombus formation (Table III). It also completely abolished platelet aggregation (postperfusion blood) by ADP and collagen in these subjects (Table II).

$M A b$ LJ-P5: normal subjects and patient C.M. As indicated above, this antibody inhibits the binding to GPIIb-IIIa of both soluble and surface-bound vWf and vitronectin, and inhibits surface-bound, but not soluble, fibronectin. In contrast, it has little or no effect on either soluble or surface-bound fibrinogen. Addition of LJ-P5 to normal blood before perfusion reduced platelet adhesion to $65 \pm 2 \%$ of control values, and was even more effective in inhibiting thrombus formation $(18 \pm 5 \%)$ (Table III).

In contrast to the above, LJ-P5 had no effect on platelet adhesion ( $98 \pm 3 \%$ of control values, $n=6)$ in patient C.M. with afibrinogenemia but, as in normal subjects, it did markedly inhibit thrombus formation ( $13 \pm 5 \%$ of control values). This antibody produced a partial inhibition of ADP and collageninduced aggregation in this patient's post-perfusion blood (Table II).

Table III. Effect of Antibodies on Platelet-Subendothelial Interaction

\begin{tabular}{|c|c|c|c|c|c|c|c|}
\hline \multirow[b]{2}{*}{ Antibody* } & \multirow{2}{*}{$\begin{array}{c}\text { Blood } \\
\text { concentration }\end{array}$} & \multicolumn{3}{|c|}{ Normal subjects } & \multicolumn{3}{|c|}{ Afibrinogenemia } \\
\hline & & $n^{*}$ & Adhesion $(C+S)$ & Thrombi (T) & $n^{*}$ & Adhesion $(C+S)$ & Thrombi (T) \\
\hline & $\mu g / m l$ & & \multicolumn{5}{|c|}{ \% control (buffer) value } \\
\hline LJ-P10 & 40 & 3 & $95 \pm 11$ & $99 \pm 23$ & ND & - & - \\
\hline Anti-Fib & 115 & 4 & $107 \pm 24$ & $90 \pm 30$ & 3 & $92 \pm 10$ & $136 \pm 25$ \\
\hline LJ-CP8 & 40 & 5 & $61 \pm 5^{\S}$ & $0^{\S}$ & 4 & $48 \pm 7^{\S}$ & $0^{\S}$ \\
\hline LJ-P5 & 40 & 5 & $65 \pm 2^{\S}$ & $18 \pm 5^{\S}$ & 6 & $98 \pm 3$ & $13 \pm 5^{\S}$ \\
\hline LJ-P5 + anti-Fib & above & ND & - & - & 3 & $96 \pm 4$ & $3 \pm 2^{\S}$ \\
\hline
\end{tabular}

* LJ-P10, CP-8 and P5 bind to GPIIb-IIIa; CP-8 and P5, but not P10, block (in varying degrees) the binding of adhesive proteins to GPIIb-IIIa. Anti-Fib, anti-fibrinogen. ${ }^{\ddagger} n=$ No. experiments (In patient C.M. with afibrinogenemia, several experiments were sometimes performed on the same day. ND, not done. ${ }^{\S}$ Values (mean \pm SEM) significantly less than controls $(P=0.05$ or less). 
MAb LJ-P5 PLUS ANTI-FIBROGEN: PATIENT C.M. Since neither antifibrinogen nor LJ-P5 alone inhibited platelet adhesion in patient C.M. with afibrinogenemia, we studied the combined effects of these antibodies on his blood. As seen in Table III, platelet adhesion was also unaffected by the two antibodies in combination, but platelet thrombi (which were already markedly reduced by LJ-P5, above) were completely eliminated. Studies on the postperfusion blood showed that the combination of the two antibodies completely inhibited platelet aggregation by ADP and collagen, similar to the findings with LJ-CP8. Platelet aggregation in PRP by thrombin (1 $\mathrm{U} / \mathrm{ml}$ ) was also completely abolished (data not shown), but some degree of aggregation occurred with $20 \mu \mathrm{g} / \mathrm{ml}$ collagen (data not shown).

MAb LJ-P10

This antibody, which binds to GPIIb-IIIa without inhibiting the binding of any adhesive protein, had no effect on either adhesion or thrombus formation in normal blood (Table III).

Studies performed at shear rate of $800 \mathrm{~s}^{-1}$

In addition to the above studies performed at a shear rate of $2,600 \mathrm{~s}^{-1}$, and a 5-min perfusion time, selected studies on normal subjects were done at a shear rate of $800 \mathrm{~s}^{-1}$. As in other studies, the results obtained with the RGDS peptide and antibodies to GPIIb-IIIa were compared with control values (Tris-saline) obtained on the same subjects. At this shear rate, the inhibitory effects of RGDS were consistently less $(71 \pm 9 \%$ of control value, $P<0.05)$ than at a shear rate of $2,600 \mathrm{~s}^{-1}$, although (as observed for the higher shear rate) thrombi were completely eliminated. Platelet adhesion was unaffected at 800 $\mathrm{s}^{-1}$ by either LJ-CP8 ( $98 \pm 6 \%$ of control value) or LJ-P5 (93 $\pm 3 \%$ of control value). Thrombi were abolished by LJ-CP8, but not by LJ-P5 ( $68 \pm 23 \%$ control value).

\section{Discussion}

The major purpose of this study was to examine the role of GPIIb-IIIa, and the four adhesive proteins known to bind to it, in mediating the interaction of platelets with the subendothelium. We utilized citrated whole blood and, in most experiments, a shear rate of $2,600 \mathrm{~s}^{-1}$. The results confirm and extend the findings of previous studies (18-20) in defining a role for GPIIb-IIIa in this process, and suggest a possible role for several adhesive proteins, but not fibrinogen, in GPIIb-IIIamediated platelet adhesion and thrombus formation on subendothelium at high shear rates.

Platelet adhesion in normal blood was decreased by two synthetic peptides which contain sequences that, in adhesive proteins, are thought to interact with GPIIb-IIIa. One of these is a dodecapeptide corresponding to the carboxyl-terminal segment of the fibrinogen $\gamma$-chain $(\gamma 400-411)(36,37,59)$; the other is a tetrapeptide (Arg-Gly-Asp-Ser) containing the RGD sequence common to fibronectin, vWf, vitronectin, and the $\gamma$-chain of fibrinogen (39-45). Both peptides have been shown to interact with the same component of the platelet membranes, presumably the GPIIb-IIIa complex $(43,45,66)$, and neither peptide affects the interaction with GPIb in the presence of ristocetin $(36,67)$. It is not clear, however, whether they actually bind to the same receptor site on GPIIb-IIIa to which adhesive proteins bind, thus inhibiting their interaction by a competitive mechanism, or in some other way modulate ligand binding to GPIIb-IIIa $(36,43,68,69)$. Platelet adhesion was also reduced (and thrombi eliminated) (Table II) by the monovalent Fab' fragment of a monoclonal antibody (LJ-CP8) against GPIIb-IIIa which completely abolishes platelet aggregation. These findings are similar to those reported in a previous study utilizing a different monoclonal antibody to GPIIb-IIIa, as well to those observed in patients with Glanzmann's thrombasthenia (18). The similar inhibitory effects on platelet adhesion obtained with the two synthetic peptides (where nonspecific steric effects are unlikely) and the Fab' fragment of LJ-CP8 provide complementary evidence that GPIIb-IIIa plays a role in mediating both platelet adhesion and thrombus formation on subendothelium under the conditions studied. Since LJ-CP8 can inhibit the binding to GPIIb-IIIa of fibrinogen, vWf, vitronectin and fibronectin [(47), Methods and Results], we attempted to determine which of these ligands might be important in GPIIb-IIIa-mediated adhesion and thrombus formation.

The results of several types of studies strongly suggested that fibrinogen is not involved. First, we observed that neither platelet adhesion nor thrombus formation was decreased in a patient with a severe congenital deficiency of this protein, and this was equally true when his blood was preincubated with an Fab anti-fibrinogen fragment in order to reduce (or eliminate) any possible effects of the trace amounts of this protein present in his blood. This antibody inhibits completely both soluble and surface-adsorbed fibrinogen and, at the concentration used, provided a 256-M excess in respect to the residual fibrinogen concentration in plasma and a 1,520-M excess in respect to platelet fibrinogen in the blood of patient C.M. Second, we utilized a monoclonal antibody (LJ-P5) to GPIIb-IIIa which had little or no effect in blocking the binding of soluble fibrinogen to platelets (46) or the adhesion of activated platelets to immobilized fibrinogen (Results). This antibody, added to normal blood, was as effective as LJ-CP8 in inhibiting platelet adhesion (Table III). The results of these two studies, extending those of previous reports $(26,27)$, strongly suggest that fibrinogen is not the protein involved in either GPIIb-IIIa mediated platelet adhesion or thrombus formation under the conditions used.

Although the above studies would appear to exclude fibrinogen as an adhesive molecule which is involved in GPIIbIIIa-mediated platelet vessel wall interaction at high shear rates, neither can they assign this role exclusively to any one of the other adhesive molecules. Since LJ-P5 inhibited the binding of both soluble and immobilized vWf and vitronectin, and had some inhibitory effect on immobilized (but not soluble) fibronectin, any of these molecules could be involved. In some studies, fibronectin has been shown to influence platelet adhesion (70-74), but recent studies by Nievelstein et al. (75) suggest that fibronectin may mediate adhesion by binding to a specific platelet receptor other than GPIIb-IIIa. In addition, since LJ-P5 inhibits thrombus formation but has no effect on the binding of soluble fibronectin to platelets, it is unlikely that fibronectin plays any significant role in GPIIb-IIIa mediated platelet-platelet interaction (cohesion). The effect of fibronectin on platelet interaction appears to be complicated, and both enhancement (70-73) and inhibition (76-79) of platelet-collagen reactions have been reported. Thus, the role of fibronectin in mediating platelet interactions requires further study.

The inhibition of platelet adhesion in normal blood by LJ-P5 (which blocks the adhesion of activated platelets to im- 
mobilized $\mathrm{vWf}$ ) suggests that $\mathrm{vWf}$ could be involved in GPIIb-IIIa-mediated platelet adhesion. This finding is consistent with more direct evidence that platelet adhesion to purified collagen was inhibited by a monoclonal antibody to vWf which selectively blocks its binding to GPIIb-IIIa (80). However, LJ-P5 also blocked the adhesion of activated platelets to surface-immobilized vitronectin, a glycoprotein involved in the adhesion of a variety of cells to matrix components through the RGD sequence $(41,81)$. Recent studies have also shown that the adsorption of vitronectin on various polymers increased platelet deposition on these polymers in a canine ex vivo model (82). Thus, a possible role for vitronectin in GPIIb-IIIa-mediated platelet adhesion cannot be ruled out. At present, we do not have any definitive explanation why LJ-P5 failed to inhibit adhesion in the patient with afibrinogenemia. It is possible that the marked decrease of fibrinogen in the platelets and plasma of the patient resulted in increased vWF binding compared to normal platelets since the two proteins compete for the GPIIb-IIIa binding site $(36,83-85)$. If, as recently shown (86), platelet $\mathrm{vWf}$ plays a role in platelet adhesion by binding predominantly to GPIIb-IIIa $(87,88)$, one could explain the somewhat increased baseline adhesion values observed in the afibrinogenemic patient by the increased membrane expression of $\mathrm{vWf}$. For reasons presently unknown, LJ-CP8 could be more effective than LJ-P5 in inhibiting the membrane binding of platelet-derived vWf, although other explanations are possible. Of interest, although LJ-P5 did not inhibit adhesion in patient C.M., it did inhibit thrombus formation, as in normal subjects (Table III). This finding provides further evidence that adhesive proteins other than fibrinogen can mediate platelet-platelet (cohesion) as well as platelet-surface reactions. Since LJ-P5 does not interfere with the binding of soluble fibronectin, it is unlikely that this protein is involved in platelet thrombus formation. The possibility that vitronectin might be involved cannot be excluded, since LJ-P5 interfered with the binding to platelets of soluble vitronectin. However, if the bridging of adhesive molecules to adjacent platelets is a plausible explanation for platelet cohesion, a role for vitronectin (which has only one RGD sequence $[89,90])$ would require that it circulate in plasma, or assemble on platelets, as functional dimers. At present, there is no evidence that this occurs. Thus, vWf, which circulates in plasma as a highly polymerized protein (3), would appear to be the most likely adhesive protein involved in GPIIb-IIIa-mediated platelet thrombus formation. This type of mechanism might also apply to other platelet cohesion processes mediated by vWf, such as platelet-platelet attachment in the aggregometer (33), on subendothelium (27), in packed bead columns (91, 92), shear fields (93-95), and glass filters (96).

The above conclusions pertaining to the role of GPIIb-IIIa and adhesive proteins in mediating platelet interaction with the subendothelium apply to the shear rate condition $(2,600$ $\mathrm{s}^{-1}$ ) that was used for most of the studies. This shear rate is typical of the microcirculation (97) and is, therefore, relevant to physiological mechanisms involved in hemostasis. Although the average shear rates in large vessels are generally lower, peak wall shear rates in pulsatile large arteries such as the aorta may well approach several thousand $\mathrm{s}^{-1}$ (98). In addition, shear rates may far exceed these values in the narrowed lumen of stenotic arteries (99). Thus, the findings and conclusions in our study could also be relevant to pathologic thrombosis.
The more limited studies done at a shear rate of $800 \mathrm{~s}^{-1}$ suggest that both the GPIIb-IIIa and adhesive ligand requirements may be different at this shear rate. For example, although both RGDS and LJ-CP8 abolished thrombi, adhesion was only moderately inhibited by RGDS and was unaffected by $\mathrm{LJ}-\mathrm{CP} 8$. In addition, the results obtained at this shear rate suggest a possible role for fibrinogen. Thrombi were considerably less inhibited by LJ-P5 (which does not block fibrinogen binding) than by LJ-CP8, suggesting that, at $800 \mathrm{~s}^{-1}$, fibrinogen could play a role in platelet-platelet interaction. Thus, the conclusion that fibrinogen is not required for platelet adhesion or thrombus formation at a shear rate of $2,600 \mathrm{~s}^{-1}$ does not preclude the possibility that it may be required when other parameters known to affect platelet-surface interactions, such as shear rate, red cell concentration, ionic milieu, and surface properties $(97,100-102)$ are different than those utilized in most of our studies. In accordance with this concept, the results that we obtained with aggregometry (Fig. 1), a more frequently used method thought to reflect platelet function, showed that the fibrinogen requirement (as assessed utilizing afibrinogenemic PRP or washed platelets) for platelet aggregation was highly dependent on the type and concentration of agonist. Thus, fibrinogen is necessary for optimal aggegation by weak agonists (such as ADP) or by relatively low concentrations of thrombin and collagen. With higher concentrations of the latter agonists, the requirement for fibrinogen to mediate platelet aggregation is not absolute, presumably because alternative mechanisms (possibly involving $\mathrm{vWf}$ released during platelet secretion) may be operative. In addition, it should be mentioned that the bleeding time is prolonged in afibrinogenemia (26), although it is possible that this is due to an absence of fibrin in the wound rather than an impairment of platelet aggregation (103).

\section{Acknowledgments}

The authors wish to thank Sashi Senrui, John Rogers, and Susan Russell for expert technical assistance, and Sheila Timmons, Dr. Marek Kloczewiak, and Dr. Maria Bednarek for preparation of antifibrinogen antibody and synthetic peptides employed in this study.

Supported in part by U. S. Public Health Service Grants HL-27346, HL-37444, HL-35103, HL-33014, HL-30648, HL-31950, HL-37522, a grant from the Charles Slaughter Foundation, and a grant-in-aid and Established Investigator Award (Dr. Thiagarajan) from the American Heart Association.

\section{References}

1. Nurden, A. T., and J. P. Caen. 1979. Different glycoprotein abnormalities in thrombasthenia and Bernard-Soulier platelets. Semin. Hematol. 16:234-250.

2. George, J. N., A. T. Nurden, and D. R. Phillips. 1984. Molecular defects in interactions of platelets with the vessel wall. N. Engl. J. Med. 311:1084-1098.

3. Zimmerman, T. S., Z. M. Ruggeri, and C. A. Fulcher. 1983. Factor VIII/von Willebrand factor. Prog. Hematol. 13:279-309.

4. Kao, K.-J., S. V. Rizzo, and P. A. McKee. 1979. Demonstration and characterization of specific binding sites for factor VIII/von Willebrand factor on human platelets. J. Clin. Invest. 63:656-664.

5. Moake, J. L., J. D. Olson, J. H. Troll, S. S. Tang, T. Funicella, and D. M. Peterson. 1980. Binding of radioiodinated human von Willebrand factor to Bernard-Soulier, thrombasthenic and von Willebrand's disease platelets. Thromb. Res. 19:21-27.

6. Coller, B. S., E. I. Peerschke, L. E. Scudder, and C. A. Sullivan. 
1983. Studies with a murine monoclonal antibody that abolishes ristocetin-induced binding of von Willebrand factor to platelets: Additional evidence in support of GPIb as a platelet receptor for von Willebrand factor. Blood 61:99-1 10.

7. Ruggeri, Z. M., L. De Marco, L. Gatti, R. Bader, and R. R. Montgomery. 1983. Platelets have more than one binding site for von Willebrand Factor. J. Clin. Invest. 72:1-12.

8. Nokes, T. C., N. A. Mahmoud, G. F. Savidge, A. H. Goodall, D. Meyer, T. S. Edgington, and R. M. Hardisty. 1984. von Willebrand factor has more than one binding site for platelets. Thromb. Res. 34:361-366.

9. Turitto, V. T., H. J. Weiss, and H. R. Baumgartner. 1983. Decreased platelet adhesion on vessel segments in von Willebrand's disease: A defect in initial platelet attachment. J. Lab. Clin. Med. 102:551-564.

10. Nieuwenhuis, H. K., K. S. Sakariassen, W. P. M. Houdijk, P. F. E. M. Nievelstein, and J. J. Sixma. 1986. Deficiency of platelet membrane glycoprotein Ia associated with a decreased platelet adhesion to subendothelium. A defect in platelet spreading. Blood. 68:692-695.

11. Tschopp, T. B., H. J. Weiss, and H. R. Baumgartner. 1974. Decreased adhesion of platelets to subendothelium in von Willebrand's disease. J. Lab. Clin. Med. 83:296-300.

12. Weiss, H. J., H. R. Baumgartner, T. B. Tschopp, V. T. Turitto, and D. Cohen. 1978. Correction by factor VIII of the impaired platelet adhesion to subendothelium in von Willebrand's disease. Blood. 51:267-279.

13. Weiss, H. J., V. T. Turitto, and H. R. Baumgartner. 1978. Effect of shear rate on platelet interaction with subendothelium in citrated and native blood. Shear-rate dependent decrease of adhesion in von Willebrand's disease and the Bernard-Soulier syndrome. J. Lab. Clin. Med. 92:750-764.

14. Weiss, H. J., T. B. Tschopp, H. R. Baumgartner, I. I. Sussman, M. M. Johnson, and J. J. Egan. 1974. Decreased adhesion of giant (Bernard-Soulier) platelets to subendothelium. Further implications on the role of the von Willebrand factor in hemostasis. Am. J. Med. 57:920-925.

15. Caen, J. P., A. T. Nurden, C. Jeanneau, H. Michel, G. Tobelem, S. Levy-Toledano, Y. Sultan, F. Valensi, and J. Bernard. 1976. Bernard-Soulier syndrome: a new platelet glycoprotein abnormality. Its relationship with platelet adhesion to subendothelium and with the factor VIII/von Willebrand protein. J. Lab. Clin. Med. 87:586-596.

16. Sakariassen, K. S., P. A. Bolhuis, and J. J. Sixma. 1979. Human blood platelet adhesion to artery subendothelium is mediated by factor VIII:vWF bound to the subendothelium. Nature (Lond.) 279:636-638.

17. Meyer, D., and H. R. Baumgartner. 1983. Role of von Willebrand factor in platelet adhesion to the subendothelium. Br. J. Haematol. 54:1-9.

18. Weiss, H. J., V. T. Turitto, and H. R. Baumgartner. 1986. Platelet adhesion and thrombus formation on subendothelium in platelets deficient in glycoproteins IIb-IIIa, Ib, and storage granules. Blood. 67:322-330.

19. Sakariassen, K. S., P. F. E. M. Nievelstein, B. S. Coller, and J. J. Sixma. 1986. The role of platelet membrane glycoproteins Ib and IIb-IIIa in platelet adherence to human artery subendothelium. $B r . J$. Haematol. 63:681-691.

20. Lawrence, J. B., and H. R. Gralnick. 1987. Monoclonal antibodies to the glycoprotein IIb/IIIa epitopes involved in adhesive protein binding. Effects on platelet spreading and ultrastructure on human arterial subendothelium. J. Lab. Clin. Med. 109:495-503.

21. Nachman, R. L., and L. L. K. Leung. 1982. Complex formation of platelet membrane glycoproteins IIb and IIIa with fibrinogen. $J$. Clin. Invest. 69:263-269.

22. Bennett, J. S., G. Vilaire, and D. B. Cines. 1982. Identification of the fibrinogen receptor on human platelets by photoaffinity labeling. J. Biol. Chem. 257:8049-8054.

23. Soria, J., C. Soria, J. Y. Borg, M. Mirshahi, H. Piguet, P. Tron, C. Fessard, and J. P. Caen. 1985. Platelet aggregation occurs in congen- ital afibrinogenaemia despite the absence of fibrinogen or its fragments in plasma and platelets, as demonstrated by immunoenzymology. $\mathrm{Br}$. J. Haematol. 60:503-514.

24. De Marco, L., A. Girolami, T. S. Zimmerman, and Z. Ruggeri. 1986. von Willebrand factor interaction with the glycoprotein II/IIIa complex: Its role in platelet function as demonstrated in patients with congenital afibrinogenemia. J. Clin. Invest. 77:1272-1277.

25. Cattaneo, M., R. L. Kinlough-Rathbone, A. Lecchi, C. Bevilacqua, M. A. Packham, and J. F. Mustard. 1987. Fibrinogen- independent aggregation and deaggregation of human platelets. Studies in two afibrinogenemic patients. Blood. 70:221-226.

26. Weiss, H. J., and J. Rogers. 1971. Fibrinogen and platelets in the primary arrest of bleeding-studies in two patients with congenital afibrinogenemia. N. Engl. J. Med. 285:369-374.

27. Turitto, V. T., H. J. Weiss, and H. R. Baumgartner. 1984. Platelet interaction with rabbit subendothelium in von Willebrand's disease: altered thrombus formation distinct from defective platelet adhesion. J. Clin. Invest. 74:1730-1741.

28. Weiss, H. J., V. T. Turitto, W. J. Vicic, and H. R. Baumgartner. 1984. Fibrin formation, fibrinopeptide $A$ release, and platelet thrombus dimensions on subendothelium exposed to flowing native blood. Greater in factor XII and XI than in Factor VIII and IX deficiency. Blood. 63:1004-1014.

29. Fujimoto, T., and J. Hawiger. 1982. Adenosine diphosphate induces binding of von Willebrand factor to human platelets. Nature (Lond.). 297:154-157.

30. Fujimoto, T., S. Ohara, and J. Hawiger. 1982. Thrombin-induced exposure and prostacyclin inhibition of the receptor for factor VIII/von Willebrand factor on human platelets. J. Clin. Invest. 69:1212-1222.

31. Ruggeri, Z. M., R. Bader, and L. De Marco. 1982. Glanzmann thrombasthenia: deficient binding of von Willebrand factor to thrombin-stimulated platelets. Proc. Natl. Acad. Sci. USA. 79:6038-6041.

32. Girma, J.-P., M. Kalafatis, G. Pietu, J.-M. Lavergne, M. W. Chopek, T. S. Edgington, and D. Meyer. 1986. Mapping of distinct von Willebrand factor domains interacting with platelet GPIb and GPIIb/IIIa and with collagen using monoclonal antibodies. Blood. 67:1356-1366.

33. Timmons, S., and J. Hawiger. 1986. von Willebrand factor can substitute for plasma fibrinogen in ADP-induced platelet aggregation. Trans. Assoc. Am. Phys. 99:226-235.

34. Plow, E. F., and M. H. Ginsberg. 1981. Specific and saturable binding of plasma fibronectin to thrombin-stimulated platelets. J. Biol. Chem. 256:9477-9482.

35. Thiagarajan, P., and K. Kelly. 1987. Exposure of binding sites for vitronectin on platelets following stimulation. J. Biol. Chem. 263:3035-3038.

36. Timmons, S., M. Kloczewiak, and J. Hawiger. 1984. ADP-dependent common receptor mechanism for binding of von Willebrand factor and fibrinogen to human platelets. Proc. Natl. Acad. Sci. USA. 81:4935-4939.

37. Plow, E. F., A. H. Srouji, D. Meyer, G. Marguerie, and M. H. Ginsberg. 1984. Evidence that three adhesive proteins interact with a common recognition site on activated platelets. J. Biol. Chem. 259:5388-5391.

38. Gralnick, H. R., S. B. Williams, and J. Hawiger. 1986. Inhibition of von Willebrand factor binding to activated platelets by the tetrapetide Arg-Gly-Asp-Ser and the dodecapeptide of fibrinogen gamma chains. Clin. Res. 34:458. (Abstr.)

39. Plow, E. F., M. D. Pierschbacher, E. Ruoslahti, G. A. Marguerie, and M. H. Ginsberg. 1985. The effect of Arg-Gly-Asp- containing peptides on fibrinogen and von Willebrand factor binding to platelets. Proc. Natl. Acad. Sci. USA. 82:8057-8061.

40. Pierschbacher, M. D., and E. Ruoslahti. 1984. Cell attachment activity of fibronectin can be duplicated by small synthetic fragments of the molecule. Nature (Lond.). 309:30-3.

41. Pytela, R., M. D. Pierschbacher, M. H. Ginsberg, E. F. Plow, and E. Ruoslahti. 1986. Platelet membrane glycoprotein IIb/IIIa: 
Member of a family of Arg-Gly-Asp-specific adhesion receptors. Science (Wash. DC) 231:1559-1562.

42. Haverstick, D. M., J. F. Cowan, K. M. Yamada, and S. A. Santoro. 1985. Inhibition of platelet adhesion to fibronectin, fibrinogen, and von Willebrand factor substrates by a synthetic tetrapeptide derived from the cell-binding domain of fibronectin. Blood. 66:946952.

43. Lam, S., M. Smith, E. Plow, A. Andrieux, J. Ryckwaert, G. Marguerie, and M. Ginsberg. 1987. Evidence that arginyl- glycilaspartate peptides and fibrinogen gamma chain peptides share a common binding site on platelets. J. Biol. Chem. 262:947-950.

44. Gartner T. K., and J. S. Bennett. 1985. The tetrapeptide analogue of the cell attachment site of fibronectin inhibits platelet aggregation and fibrinogen binding to activated platelets. J. Biol. Chem. 260:11891-11894.

45. Phillips, D. R., I. F. Charo, L. V. Parise, and L. A. Fitzgerald. 1988. The platelet membrane glycoprotein IIb-IIIa complex. Blood. 71:831-843

46. Lombardo, V. T., E. Hodson, J. R. Roberts, T. J. Kunicki, T. S. Zimmerman, and Z. M. Ruggeri. 1985. Independent modulation of von Willebrand factor and fibrinogen binding to the platelet membrane glycoprotein IIb/IIIa complex as demonstrated by monoclonal antibody. J. Clin. Invest. 76:1950-1958.

47. Niiya, K., E. Hodson, R. Bader, V. Byers-Ward, J. A. Koziol, E. F. Plow, and Z. M. Ruggeri. 1987. Increased surface expression of the membrane glycoprotein IIb/IIIa complex induced by platelet activation. Relationship to the binding of fibrinogen and platelet aggregation. Blood. 70:475-483.

48. Turitto, V. T., and H. R. Baumgartner. 1979. Platelet interaction with subendothelium in flowing rabbit blood: Effect of blood shear rate. Microvasc. Res. 17:38-54.

49. Baumgartner, H. R. 1973. The role of blood flow in platelet adhesion, fibrin deposition and formation of mural thrombi. Microvasc. Res. 5:167-179.

50. Weiss, H. J., L. D. Witte, K. L. Kaplan, B. A. Lages, A. Chernoff, H. L. Nossel, De W. S. Goodman, and H. R. Baumgartner. 1979. Studies on granule-bound substances in 18 patients including variants deficient in $\alpha$-granules, platelet factor $4, \beta$-thromboglobulin and platelet-derived growth factor. Blood. 54:1296-1319.

51. Walsh, P. N., D. C. B. Mills, and J. G. White. 1977. Metabolism and function of human platelets washed by albumin density gradient separation. Br. J. Haematol. 36:281-296.

52. Lages, B., M. C. Scrutton, and H. Holmsen. 1975. Studies on gel-filtered human platelets: isolation and characterization in a medium containing no added $\mathrm{Ca}^{+2}, \mathrm{Mg}^{+2}$, or $\mathrm{K}^{+}$. J. Lab. Clin. Med. 85:811-825.

53. Dahlback, B., and E. R. Podack. 1985. Characterization of Human $S$ protein, an inhibitor of the membrane attack complex of complement. Demonstration of a free reactive thiol group. Biochemistry. 24:2368-2374.

54. Bolton, A. E., and W. M. Hunter. 1973. The labelling of proteins to high specific activities by conjugation to a ${ }^{125}$ I containing acylating agent. Biochem. J. 133:529-537.

55. Haverstick, D. M., J. F. Cowan, K. M. Yamada, and S. A. Santoro. 1985. Inhibition of platelet adhesion to fibronectin, fibrinogen and von Willebrand factor substrates by a synthethic tetrapeptide derived from the cell binding domain of fibronectin. Blood. 66:946952.

56. Martinez, J., R. R. Holburn, S. S. Shapiro, and A. J. Erslev 1974. Fibrinogen Philadelphia: A hereditary hypofibrinogenemia characterized fibrinogen increased catabolism. J. Clin. Invest. 53:600603.

57. Engvall, E., and E. Ruoslahti. 1977. Binding of soluble form of fibroblast surface protein, fibronectin to collagen. Int. J. Cancer 20:1-5.

58. Baenziger, N. L., and P. W. Majerus. 1974. Isolation of human platelets and platelet membranes. Methods Enzymol. 31:149-155.

59. Kloczewiak, M., S. Timmons, and J. Hawiger. 1984. Platelet receptor recognition site on human fibrinogen. Synthesis and structure-function relationship of peptides corresponding to the carboxyterminal segment of the gamma chain. Biochemistry. 23:1767-1774.

60. Barany, G., and R. B. Merrifield. 1980. In The Peptides: Analysis, Synthesis, Biology. E. Gross and J. Meinhoper, editors. Academic Press, Inc., New York. 284.

61. Hawiger, J., S. Timmons, M. Kloczewiak, D. D. Strong, and R. F. Doolittle. 1982. Gamma and alpha chains of human fibrinogen possesses sites reactive with human platelet receptors. Proc. Natl. Acad. Sci. USA. 79:2068-2071.

62. Porter, R. R. 1959. The hydrolysis of rabbit gamma-globulin and antibodies with crystalline papain. Biochem. J. 73:119-126.

63. Kaplan, K. L., and J. Owen. 1982. Radioimmunoassay of platelet factor 4. Methods Enzymol. 84:83-92.

64. Owen, J., K. D. Friedman, B. A. Grossman, C. Wilkins, A. D. Berke, and E. R. Powers. 1987. Quantitation of fragment X formation during thrombolytic therapy with streptokinase and tissue plasminogen activator. J. Clin. Invest. 79:1642-1647.

65. Weiss, H. J., G. Pietu, D. Meyer, R. Rabinowitz, J. P. Girma, and J. Rogers. 1983. Heterogeneous abnormalities in the multimeric structure, antigenic properties, and plasma/platelet content of FVIII/ vWF in classical (Type I) and three sub-types of variant (Type II) von Willebrand's disease. J. Lab. Clin. Med. 101:411-425.

66. Gartner, T. K., J. W. Power, E. H. Beachy, J. S. Bennett, and S. J. Shatill. 1985. The tetrapeptide analogue of the alpha chain and decapeptide analogue of the gamma chain of fibrinogen bind to different sites on the platelet fibrinogen receptor. Blood. 66:305a. (Abstr.)

67. Plow, E. F., M. D. Pierschbacher, E. Ruoslahti, G. A. Marguerie, and M. H. Ginsberg. 1985. The effect of Arg-Gly-Asp-containing peptides on fibrinogen and von Willebrand factor binding to platelets. Proc. Natl. Acad. Sci. USA. 82:8057-8061.

68. Peerschke E. I. B., and D. K. Galanakis. 1983. Binding of fibrinogen to ADP-treated platelets. Comparison of plasma fibrinogen fractions and early plasmic fibrinogen derivatives. J. Lab. Clin. Med. 101:453-460.

69. Peerschke, E. I. B., and D. K. Galanakis. 1987. The synthetic RGDS peptide inhibits the binding of fibrinogen lacking intact $\alpha$ chain carboxyterminal sequences to human blood platelets. Blood. 69:950952.

70. Houdijk, S. P. M., and J. J. Sixma. 1985. Fibronectin in artery subendothelium is important for platelet adhesion. Blood. 65:598604.

71. Houdijk, W. P. M., K. S. Sakariassen, P. F. E. M. Nievelstein, and J. J. Sixma. 1985. Role of factor VIII-von Willebrand factor and fibronectin in the interaction of platelets in flowing blood with moneric and fibrillar human collagen types I and III. J. Clin. Invest. 75:531-540.

72. Hoffmann, R. P., and R. O. Hynes. 1980 . The role of fibronectin in the adhesion of platelets to collagen. Clin. Res. 28:297a. (Abstr.)

73. Koteliansky, V. E., N. L. Leytin, D. D. Svirdov, V. S. Repin, and V. N. Smirnov. 1981. Human plasma fibronectin promotes the adhesion and spreading of platelets on surfaces coated with fibrillar collagen. FEBS (Fed. Eur. Biol. Soc.) Lett. 123:59-62.

74. Bastida, E., G. Escolar, A. Ordinas, and J. J. Sixma. 1987. Fibronectin is required for platelet adhesion and for thrombus furnation on subendothelium and collagen surfaces. Blood. 70:1437-1442.

75. Nievelstein, P. F. E. M., M. Ottenhof-Robers, M. D. Pierschbacher, and J. J. Sixma. 1987. The Arg-Gly-Asp (Ser) sequence of fibronectin, and the glycoprotein IIb-IIIa complex are not involved in fibronectin-dependent platelet adhesion in flow. Thromb. Haemostasis 58:213a. (Abstr.)

76. Santoro, S. A. 1983. Inhibition of platelet aggregation by fibronectin. Biochem. Biophys. Res. Commun. 116:135-140.

77. Sochynsky, R. A., B. J. Boughton, J. Burns, B. C. Sykes, and J. O'D. McGee. 1980. The effect of human fibronectin on platelet-collagen adhesion. Thromb. Res. 18:521-523.

78. Aihara, M. H. Takami, Y. Sawada, S. Morimoto, K. Kariya, I. Kudo, K. Ueno, A. Kimura, and Y. Yoshida. 1986. Effect of fibronec- 
tin and von Willebrand factor on the adheion of human fixed washed platelets to collagen immobilized beads. Thromb. Res. 44:661-672.

79. Moon, D. G., J. E. Kaplan, and J. E. Muzurkiewicz. 1986. The inhibitory effect of plasma fibrinectin on collagen-induced platelet aggregation. Blood. 67:450-457.

80. Fressinaud E., K. S. Sakariassen, J. P. Girma, D. Meyer, and H. R. Baumgartner. 1986. Role of GPIIb/IIIa as well as GPIb in von Willebrand factor-mediated platelet adhesion to collagen. Thromb. Res. (Suppl. VI):138 (Abstr.)

81. Ruoslahti, E., E. G. Hayman, and M. D. Pierschbacher. 1985. Extracellular matrices and cell adhesion. Arteriosclerosis. 5:581-594.

82. Collins, W. E., D. F. Mosher, B. R. Tomasini, and S. L. Cooper. 1988. A preliminary comparison of the thrombogenic activity of vitronectin and other RGD-containing proteins when bound to surfaces. Ann. NY Acad. Sci. 516:291-299.

83. Pietu, G., G. Cherel, G. Marguerie, and D. Meyer. 1984. Inhibition of von Willebrand factor-platelet interaction by fibrinogen. $\mathrm{Na}$ ture (Lond.). 308:648-649.

84. Schullek, J., J. Jordan, and R. R. Montgomery. 1984. Interaction of von Willebrand factor with human platelets in the plasma milieu. J. Clin. Invest. 73:421-428.

85. Gralnick, H. R., S. B. Williams, and B. S. Coller. 1984. Fibrinogen competes with von Willebrand factor for binding to the glycoprotein IIb/IIIa complex when platelets are stimulated with thrombin. Blood. 64:797-800.

86. Fressinaud, E., D. Baruch, C. Rothschild, H. R. Baumgartner, and D. Meyer. 1986. Platelet von Willebrand factor: evidence for its involvement in platelet adhesion to collagen. Blood. 66:316a. (Abstr.)

87. Parker, R. I., and H. R. Gralnick. 1986. Identification of platelet glycoprotein IIb/IIIa as the major binding site for released plateletvon Willebrand factor. Blood. 68:732-736.

88. Furby, F. H., M. C. Berndt, P. A. Castaldi, and J. Koutts. 1984. Characterization of calcium-dependent binding of endogenous factor VIII/von Willebrand factor to surface activated platelets. Thromb. Res. 35:501-511.

89. Jenne, D., and K. K. Stanley. 1986. Molecular cloning of Sprotein, a link between complement, coagulation and substrate adhesion. Eur. Mol. Biol. Organ. J. 4:3153-3157.

90. Suzuki, S., A. Oldberg, E. G. Hayman, M. D. Pierschbacher, and E. Ruoslahti. 1985. Complete amino acid sequence of human vitronectin deduced from cDNA. Similarity of cell attachment sites in vitronectin and fibronectin. Eur. Mol. Biol. Organ. J. 4:2519-2524.

91. McPherson, J., and M. B. Zucker. 1976. Platelet retention in glass bead columns. Adhesion to glass and subsequent platelet-platelet interaction. Blood. 47:55-67.

92. McPherson, J., S. Brownlea, and M. B. Zucker. 1987. Effect of monoclonal antibodies against von Willebrand factor and platelet glycoproteins IIb/IIIa on the platelet retention test. Blood. 70:546-550.

93. Moake, J. L., N. A. Turner, N. A. Stathopoulos, L. H. Nolasco, and J. D. Hellums. 1986. Involvement of large plasma von Willebrand factor (vWF) multimers and unusually large vWF forms derived from endothelial cells in shear stress-induced platelet aggregation. J. Clin. Invest. 78:1456-1462.

94. Joist, J. H., E. J. Bauman, M. Speer, and S. P. Sutera. 1985. Role of platelet surface interaction in fluid shear-induced platelet aggregation. Thromb. Haemostasis. 54:109. (Abstr.).

95. Peterson, D. M., N. A. Stathopoulos, T. D. Giorgio, J. D. Hellums, and J. L. Moake. 1987. Shear-induced platelet aggregation requires von Willebrand factor and platelet membrane glycoproteins Ib and IIb-IIIa. Blood. 69:625-628.

96. O'Brien, J. R., and G. P. Salmon. 1987. Shear stress activation of platelet glycoprotein IIb/IIIa plus von Willebrand factor causes aggregation. Filter blockage and the long bleeding time in von Willebrand's disease. Blood. 70:1354-1361.

97. Turitto, V. T., and H. R. Baumgartner. 1986. Platelet-surface interactions. In Hemostasis and Thrombosis-Basic Principles and Clinical Practice. R. W. Colman, J. Hirsh, V. J. Marder, and C. W. Salzman, editors. J. B. Lippincott, Philadelphia. 555-571.

98. Goldsmith, H. L., and V. T. Turitto. 1986. Rheological aspects of thrombosis and haemostasis: basic principles and applications. Thromb. Haemostasis. 55:415-435.

99. Back, L. H., J. R. Radbill, and D. W. Crawford. 1977. Analysis of pulsatile viscous blood flow through diseased coronary arteries of man. J. Biomech. 10:339-353.

100. Adams, G. A. 1985. Platelet adhesion: past and present. In The Platelets: Physiology and Pharmacology. G. L. Longenecker, editor. Academic Press, Inc., Orlando, FL. 15-47.

101. Nossel, H. L. 1972. Platelets, surfaces and plasma proteins in platelet adhesion. In Platelets, Drugs, and Thrombosis. J. Hirsh, editor. S. Karger, Basel. 15-26.

102. Sakon, M., and J. Hawiger. 1984. Mechanism triggering platelet hemostatic plug formation in vivo. Trans. Assoc. Am. Phys. 97:311-318

103. Weiss, H. J., and B. Lages. 1988. Evidence for tissue factordependent activation of the classic extrinsic coagulation mechanism in blood obtained from bleeding time wounds. Blood. 71:629-635. 